\title{
Changes in the Antioxidant System Associated with Budbreak in 'Anna' Apple (Malus domestica Borkh.) Buds
}

\author{
Shiow Y. Wang and Miklos Faust \\ Fruit Laboratory, Beltsville Agriculture Research Center, Agriculture Research Service, U.S. Department \\ of Agriculture, Beltsville, MD 20705
}

\begin{abstract}
Additional index words. ascorbate free radical reductase, ascorbate oxidase, ascorbate peroxidase, ascorbic acid, dehydroascorbate reductase, dehydroascorbic acid, disulfide, dormancy, glutathione, glutathione reductase, temperature, thiols

Abstract. The ability of low and high temperatures and S-containing compounds to overcome endo- and paradormancy along with the possible mechanisms involved in these treatments for breaking 'Anna' apple bud dormancy were studied. All three treatments induced budbreak in paradormant (July) and endodormant (October) buds. Cold, heat, and allyl disulfide increased ascorbic acid, the reduced form of glutathione (GSH), total glutathione, total nonprotein thiol (NPSH), and nonglutathione thiol (RSH), whereas dehydroascorbic acid and oxidized glutathione (GSSG) decreased. The treatments also increased the ratios of ascorbic acid : dehydroascorbate and GSH : GSSG and the activities of ascorbate free-radical reductase (AFR, EC 1.6.5.4), ascorbate peroxidase (EC 1.11.1.11), dehydroascorbate reductase (DHAR, EC 1.8.5.1), ascorbate oxidase (AAO, EC 1.10.3.3), and glutathione reductase (GR, EC 1.6.4.2) in the buds. These results indicate that budbreak induced by cold, heat, and allyl disulfide is associated with the removal of free radicals through activated peroxide-scavenging systems.
\end{abstract}

Temperate-zone fruit trees may become dormant during the winter (endodormant) and summer (paradormant). The mechanisms of the two dormant periods are considered to be different. Endodormancy requires chilling at low temperatures ( 2 to $9 \mathrm{C}$ ) to break dormancy, whereas paradormancy does not require chilling and can be terminated by removing the terminal bud.

The amount of chilling required for breaking endodormancy depends on the cultivar (Saure, 1985). The effects of chilling can be negated in apple and peach by temperatures of 15 to 30C (Erez and Lavee, 1971; Young, 1992). High temperatures (30 to 50C) have also been reported to overcome endodormancy. Molisch (1908) found that dipping various species of dormant shrubs or cut branches into hot water (30 to 40C) for $12 \mathrm{~h}$ could overcome endodormancy. Steam had a similar effect (Boresch, 1924). Orffer and Goussard (1980) have shown that a 50C water dip for $30 \mathrm{~min}$ released grape cuttings from endodormancy. Shirazi and Fuchigami (1992) also found that high temperature (47C) for $1 \mathrm{~h}$ overcame endodormancy in Red-Osier dogwood plants.

Several compounds such as dinitro-ortho-cresol (DNOC), $\mathrm{KNO}_{3}$, thiourea, benzyladenine (BA), gibberellins, and thidiazuron ( $N$-phenyl- $N$ '-1,2,3-thidiazol-5-ylurea) have been used as sprays to break dormancy when chilling is insufficient (Erez and Lavee, 1971; Steffens and Stutte, 1989; Wang et al., 1986). Sulfur-containing compounds- $-\mathrm{H}_{2} \mathrm{~S}, \mathrm{SO}_{2}$, allyl sulfide, methyl disulfide, and allyl isothiocyanate - also accelerated budbreak or sprouting in corms, tubers, trees, and grapes (Hosoki et al., 1986; Hosoki and Kubara, 1989; Kubota and Kawazu, 1992; Kubota and Miyamuki, 1992). There are no reports on the effects of chilling and heat on removing paradormancy.

Fuchigami and Nee (1987) speculated that glutathione is involved in overcoming endodormancy in temperate woody perennials. Siller-Cepeda et al. (1992) found that the increase of the reduced form of glutathione (GSH) during chilling was closely

Received for publication 31 Mar. 1993. Accepted for publication 10 Jan. 1994. The cost of publishing this paper was defrayed in part by the payment of page charges. Under postal regulations, this paper therefore must be hereby marked advertisement solely to indicate this fact. associated with the breaking of rest in peach buds. Hydrogen cyanamide, a dormancy-breaking chemical, rapidly decreases GSH content in peach buds within $12 \mathrm{~h}$ of application. Twenty-four hours after application, a significant increase in GSH content was observed (Siller-Cepeda et al., 1992). We previously reported an increase in ascorbate, total glutathione, and related enzyme activities after thidiazuron-induced apple budbreak (Wang et al., 1991a).

The objectives of the present study were to determine the effect of high temperature (40 to 50C) and S-containing compounds on breaking endo- and paradormancy, evaluate the effect of cold on removing paradormancy, and examine possible mechanisms whereby these treatments break bud dormancy in apple.

\section{Materials and Methods}

Effect of chilling units (CUs) on budbreak during paradormancy (Expt. 1). Vegetative buds of 'Anna' apple were used. Shoots were collected in July 1992, defoliated (blade removed, petiole retained), wrapped in plastic, and stored in a room maintained at 4C. Each hour at $4 \mathrm{C}$ was considered $1 \mathrm{CU}$. Twenty shoots were taken from cold storage after receiving either $0,200,400,600$, or 800 CUs. Three replications were used for each treatment. Shoots were placed with their basal ends in glass jars containing distilled water at 22 to $24 \mathrm{C}$ for 3 weeks to observe budbreak. Basal ends were recut, water was changed, and budbreak was recorded at 3-day intervals.

Effect of hot water on bud break during endodormancy and paradormancy (Expt. 2). 'Anna' shoots were collected in July and late October 1992. Hot water at 20,40,45, or 50C was used. Treatments consisted of conditions where either a) entire shoots were immersed in hot water or b) only the basal ends of shoots, $\approx 2.5$ $\mathrm{cm}$ in length, were immersed in hot water. The duration of each hot water treatment was $1 \mathrm{~h}$. Twenty shoots were used for each treatment, and each treatment had three replications. Budbreak was determined as described in Expt. 1.

Breaking endo-and paradormancy by S-containing compounds (Expt. 3). 'Anna' shoots were collected in July and late October 1992 and placed with their basal ends in glass jars containing 
distilled water at 22 to 24C. Each jar was exposed to the vapors of $10 \mathrm{ml}$ of different concentrations $(0 \%, 10 \%, 30 \%, 60 \%)$ of three S-containing compounds (allyl disulfide, methyldisulfide, and allyl mercaptan) (Aldrich, Milwaukee) for $24 \mathrm{~h}$ in a 12-liter desiccator. Ten shoots were used for each treatment, and each treatment had three replications. Bud browning indicated that phytotoxicity had occurred. Budbreak was determined as described in Expt. 1.

Determination of ascorbate and dehydroascorbate (Expt. 4). Buds used for biochemical analysis and enzymatic assays were sampled 2 days after treatment for all experiments (Expts. 1 to 3). Triplicate bud samples of $200 \mathrm{mg}$ fresh weight were used for each treatment. Excised bud tissue was immediately homogenized with a cold mortar and pestle using 5\% (w/v) trichloroacetic acid containing $80 \mathrm{mg}$ polyclar AT and $400 \mathrm{mg}$ sea sand. The ratio of the bud tissue to the homogenizing medium was $1: 1(\mathrm{w} / \mathrm{v})$. The homogenate was filtered through four layers of Miracloth (Calbiochem, La Jolla, Calif.) and centrifuged at $16,000 \times g$ for 10 min at $4 \mathrm{C}$. The supernatant was used for the ascorbate and total ascorbate assay. Ascorbate and dehydroascorbate levels were determined using the method of Arakawa et al. (1981) and Nakagawara and Sagisaka (1984). This assay is based on the reduction of ferric ion to ferrous ion with ascorbic acid in acid solution followed by formation of the red chelate between ferrous ion and 4,7-diphenyl-1,10-phenantrolin (bathophenanthroline) that absorbs at $534 \mathrm{~nm}$. Total ascorbate (ascorbate plus dehydroascorbate) was determined by the reduction of dehydroascorbate to ascorbate by dithiothreitol.

The ascorbate assay mixture contained $0.1 \mathrm{ml}$ of the sample extract, $0.5 \mathrm{ml}$ of absolute ethanol, $0.6 \mathrm{M}$ trichloroacetic acid, $3 \mathrm{~mm}$ bathophenanthroline, $8 \mathrm{~mm} \mathrm{H}_{3} \mathrm{PO}_{4}$, and $0.17 \mathrm{~mm} \mathrm{FeCl}_{3}$. The final volume was $1.5 \mathrm{ml}$, and the solution was allowed to stand at 30C for 90 min to allow the $\mathrm{Fe}^{+2}$-bathophenanthroline complex to develop. The absorbance of the colored solution was read at 534 $\mathrm{nm}$. The total ascorbate assay mixture contained $0.1 \mathrm{ml}$ of the sample solution, $0.15 \mathrm{ml}$ of $3.89 \mathrm{~mm}$ dithiothreitol, and $0.35 \mathrm{ml}$ of absolute ethanol in a total volume of $0.6 \mathrm{ml}$. The reaction mixture was left standing at room temperature for $10 \mathrm{~min}$. After dehydroascorbate was reduced to ascorbate, $0.15 \mathrm{ml}$ of $20 \%$ trichloroacetic acid was added. The color was developed by adding the following reagents in this sequence: $0.15 \mathrm{ml}$ of $0.4 \%(\mathrm{v} / \mathrm{v})$ $\mathrm{H}_{3} \mathrm{PO}_{4}$-ethanol, $0.3 \mathrm{ml}$ of $0.5 \%$ (w/v) bathophenanthroline-ethanol, and $0.15 \mathrm{ml}$ of $0.03 \%(\mathrm{w} / \mathrm{v}) \mathrm{FeCl}_{3}$-ethanol. The final volume was $1.5 \mathrm{ml}$, and, after incubation at $30 \mathrm{C}$ for $90 \mathrm{~min}$, the absorbance at $534 \mathrm{~nm}$ was recorded. Dehydroascorbate concentrations were estimated from the difference of total ascorbate and ascorbate concentration. A standard curve of 0 to $10 \mu \mathrm{mol}$ ascorbate or dehydroascorbate was used.

Measurement of nonprotein thiol(NPSH), nonglutathione thiol (RSH), and total glutathione (Expt. 5). Bud samples were collected as described in Expt. 4. Buds (200 mg) were homogenized in 2.0 $\mathrm{ml}$ ice-cold, degassed $7.57 \mathrm{~mm}$ sodium ascorbate solution with chilled mortar and pestle under $\mathrm{N}_{2}$ at $0 \mathrm{C}$. The homogenate was filtered through four layers of Miracloth and the filtrate was centrifuged at $30,000 \times g$ for $15 \mathrm{~min}$ at $0 \mathrm{C}$. The supernatant was deproteinized in glass test tubes by incubating in a water bath at $100 \mathrm{C}$ for $3 \mathrm{~min}$ and then centrifuged at $15,000 \times \mathrm{g}$ for $15 \mathrm{~min}$ at $0 \mathrm{C}$. The supernatants were used to determine NPSH and total glutathione.

Total NPSH was determined following titration with 5,5'-dithio-bis-(2-nitrobenzoic acid) (DTBN) as described by Ellman (1959).

Total glutathione was determined specifically by a modifica- tion of the cycling enzyme assay of Guy and Carter (1982). Total glutathione equivalents were determined by reacting $0.1 \mathrm{ml}$ extract with $0.125 \mathrm{~mm} \mathrm{NaH}_{2} \mathrm{PO}_{4}, 0.28 \mathrm{~mm}$ DTBN in $200 \mathrm{~mm}$ tris-HCL ( $\mathrm{pH}$ 8.0), 3 units glutathione reductase [GR (from spinach), EC 1.6.4.2], and $0.5 \mathrm{~mm}$ NADPH. The reaction was followed as the rate of change in absorbance at $412 \mathrm{~nm}$ by a spectrophotometer (UV-160A; Shimadzu, Columbia, Md.), and the total glutathione content was calculated from a standard curve. Oxidized glutathione (GSSG) was determined after GSH was removed from the sample extract. GSH was removed from the reaction mixture by mixing $0.4 \mathrm{ml}$ extract with $0.5 \mathrm{ml} 1.25 \mathrm{M} \mathrm{NaH}_{2} \mathrm{PO}_{4}$ and $0.1 \mathrm{ml} 100 \mathrm{~mm}$ $\mathrm{N}$-ethylmaleimide (NEM) in $125 \mathrm{~mm} \mathrm{NaH}_{2} \mathrm{PO}_{4}$. The mixture was allowed to stand at room temperature for $70 \mathrm{~min}$, after which excess NEM was removed by repeated solvent extraction (five times) with an equal volume of ether. Residual ether was removed by bubbling an $\mathrm{N}$ stream through the solution. A portion $(100 \mu \mathrm{l})$ of the resultant solution was assayed as above. GSH was determined by subtracting GSSG from total glutathione. The value obtained from the difference between NPSH and GSH represented RSH.

Ascorbate free radical reductase (AFR, EC 1.6.5.4), ascorbate peroxidase (EC 1.11.1.11), and dehydroascorbate reductase (DHAR, EC 1.8.5.1) (Expt. 6). Bud samples were collected as described in Expt. 4. Bud tissue (200 mg) was homogenized in 2.0 $\mathrm{ml}$ of cold $50 \mathrm{~mm}$ tris- $\mathrm{HCl}$ ( $\mathrm{pH} 7.7$ ) containing $2 \mathrm{~mm}$ dithiothreitol, $80 \mathrm{mg}$ polyclar AT, and $400 \mathrm{mg}$ sea sand with chilled mortars and pestles. The homogenate was filtered through four layers of Miracloth and centrifuged at $16,000 \times g$ for $10 \mathrm{~min}$ at $0 \mathrm{C}$. The supernatant was used for enzyme assays.

AFR activity was assayed according to the procedure of Arrigoni et al. (1981) by measuring the rate of NADH oxidation at $340 \mathrm{~nm}$. The reaction mixture contained $50 \mathrm{~mm}$ potassium phosphate $(\mathrm{pH}$ 7.3), 0.2 mм NADH, $1.0 \mathrm{~mm}$ ascorbate, 1.0 unit ascorbate oxidase (from cucurbita, EC 1.10.3.3), and $0.1 \mathrm{ml}$ of crude enzyme. The reaction was started by adding ascorbate oxidase.

The ascorbate peroxidase activity was assayed according to the method of Shigeoka et al. (1980), which consisted of measuring the oxidation of ascorbate at $290 \mathrm{~nm}$. The reaction mixture contained $25 \mathrm{~mm}$ potassium phosphate $(\mathrm{pH} 6.1), 0.2 \mathrm{~mm}$ ascorbate, $0.1 \mathrm{~mm}$ $\mathrm{H}_{2} \mathrm{O}_{2}$, and $0.1 \mathrm{ml}$ of crude enzyme. The reaction was started by adding $\mathrm{H}_{2} \mathrm{O}_{2}$.

The DHAR activity was assayed by measuring the rate of NADPH oxidation at $340 \mathrm{~nm}$ (Shigeoka et al., 1980). The reaction mixture contained $50 \mathrm{~mm}$ potassium phosphate ( $\mathrm{pH} 6.1$ ), $0.2 \mathrm{~mm}$ NADPH, $2.5 \mathrm{~mm}$ dehydroascorbate, $2.5 \mathrm{~mm}$ glutathione, 0.6 unit $\mathrm{GR}$, and $0.1 \mathrm{ml}$ of crude enzyme. The reaction was started by adding dehydroascorbate.

Ascorbic acid oxidase (AAO, EC 1.10.3.3) (Expt. 7). Bud samples were collected as described in Expt. 4. Excised bud tissue (200 mg) was immediately ground in a cool mortar and pestle with $400 \mu \mathrm{l}$ of $100 \mu \mathrm{M}$ leupeptin (Sigma, St. Louis). The homogenate was mixed with $1600 \mu$ l of 0.1 M sodium citrate buffer (pH 5.6) and centrifuged at $800 \times g$ for $20 \mathrm{~min}$ at $0 \mathrm{C}$ to obtain clear supernatant. The ionic strength of the buffer was high enough to elute AAO activity from the wall residue (Lin and Varner, 1991). This supernatant fraction was used for assaying AAO activity. AAO was determined using an $\mathrm{O}_{2}$ electrode (model 53; YSI, Yellow Springs, Ohio) by measuring $\mathrm{O}_{2}$ consumption at $28 \mathrm{C}$. The reaction mixture contained $1.5 \mathrm{ml}$ of $0.1 \mathrm{M}$ sodium citrate buffer adjusted with $1 \mathrm{M} \mathrm{HCl}$ or $\mathrm{NaOH}$ to the desired $\mathrm{pH}$ value, $0.3 \mathrm{ml}$ of $10 \mathrm{~mm}$ $\mathrm{Na}$ ascorbate, $1.15 \mathrm{ml}$ double-distilled $\mathrm{H}_{2} \mathrm{O}$, and $50 \mu \mathrm{l}$ of crude enzyme extract. Enzyme activity was expressed as nmol $\mathrm{O}_{2}$ consumed/min per $\mu \mathrm{g}$ protein. Protein content was determined accord- 
ing to Bradford (1976) using bovine serum albumin as a standard. GR (Expt. 8). Bud samples were collected as described in Expt. 4. Excised bud tissue $(200 \mathrm{mg})$ was immediately pulverized in a cold mortar and pestle with $2 \mathrm{ml}$ cold $0.1 \mathrm{~m}$ tris- $\mathrm{HCl}(\mathrm{pH} 7.5)$ containing 0.05 mM EDTA, $9.94 \mathrm{~mm}$ isoascorbate, $40 \mathrm{mg}$ insoluble polyvinylpyrrolidone (PVP), and $400 \mathrm{mg}$ sea sand. The homogenate was filtered through four layers of Miracloth and centrifuged at $20,000 \times g$ for $20 \mathrm{~min}$ at $0 \mathrm{C}$. The supernatant was used for GR assay. The assay mixture contained $50 \mathrm{~mm}$ tris- $\mathrm{HCl}(\mathrm{pH} 7.5), 3 \mathrm{~mm}$ $\mathrm{MgCl}_{2}, 0.15 \mathrm{~mm} \mathrm{NADPH}, 10 \mathrm{~mm}$ GSSG, and $0.1 \mathrm{ml}$ of crude enzyme extract. The total reaction volume was $1.0 \mathrm{ml}$. GR activity was assayed by monitoring glutathione-dependent oxidation of NADPH at $340 \mathrm{~nm}$ (Foyer and Halliwell, 1976). The reaction was started by adding GSSG. Protein was determined according to Bradford (1976) using bovine serum albumin as a standard.

\section{Results and Discussion}

Cold-induced budbreak. The amount of low temperature required to overcome bud dormancy is generally referred to as the chilling requirement for endodormancy of winter buds (Saure, 1985). However, little attention has been given to the effect of low temperature on paradormancy of summer buds in fruit trees.

Low temperature induced budbreak in paradormant 'Anna' buds that were collected in July 1992 (Fig. 1). A small amount of budbreak occurred with $0 \mathrm{CU}$, but a higher percentage of budbreak started after the buds were exposed to 200 CUs. 'Anna' buds required $600 \mathrm{CUs}$ to achieve maximum budbreak for axillary $(89.0 \%)$ and terminal $(96.0 \%)$ buds, and budbreak leveled off with additional CU accumulation. The wound ethylene produced by shoots excision and petiole removal were minimal (data not shown). Thus, ethylene may not be involved directly in breaking paradormancy. Paiva and Robitaille (1978) and Zimmerman et al. (1977) found no evidence that ethylene was involved in breaking dormancy of 'Golden Delicious' apple and crabapple. Therefore, cold seems to break paradormancy effectively.

Heat-induced budbreak. Hot water induced budbreak in endoand paradormant buds (Figs. 2 and 3). Increasing the water temperature up to $45 \mathrm{C}$ increased the percentage of budbreak. The optimal water temperature for budbreak was 40 to $45 \mathrm{C}$. Higher water temperatures (50C) reduced the percentage of budbreak. Terminal buds were more responsive to hot water treatments and resulted in a higher percentage of budbreak compared to axillary

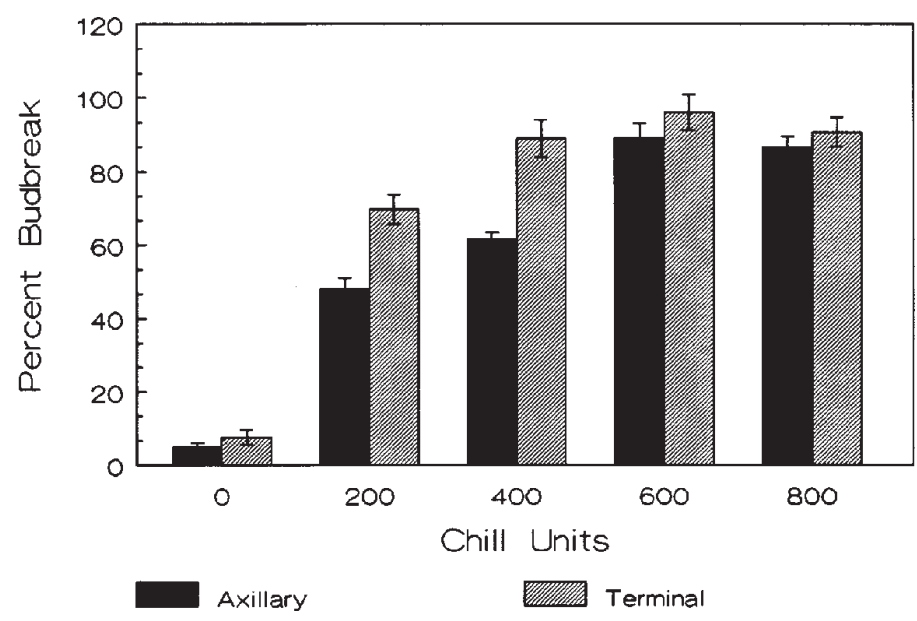

Fig. 1. Effect of low temperatures on budbreak of defoliated paradormant apple cuttings (after 21 days). 1 Chilling unit $(\mathrm{CU})=1 \mathrm{~h}$ at $4 \mathrm{C}$. Vertical bars represent mean of three replications \pm SE. buds. Shoot immersion enhanced budbreak compared to treatments during which only the basal ends were submerged. Immersing shoots into 50C hot water caused bud dieback; therefore, the percentage of budbreak was reduced.

Induced budbreak with S-containing compounds. Exposing apple shoots to vapors of $10 \%, 30 \%$, and $60 \%$ allyl disulfide for 24 h promoted budbreak measurably without phytotoxicity (browning). Ten percent allyl disulfide was sufficient to break paradormancy (Fig. 4) and endodormancy (Fig. 5). The effect was more pronounced in terminal than in axillary buds. Higher concentrations (30\% and 60\%) did not increase budbreak further. Methyl disulfide and allyl mercaptan volatiles at concentrations of $10 \%$ to $60 \%$ had no effect in breaking dormancy and also caused phytotoxic symptoms in all shoots tested (data not shown).

Changes of ascorbic acid, dehydroascorbic acid, and enzyme activities related to ascorbate metabolism in apple buds treated with cold temperature, hot water, and allyl disulfide. Budbreak induced by cold, heat, allyl disulfide, or as reported previously by thidiazuron (Wang et al., 1991a) shows an increase in ascorbic acid

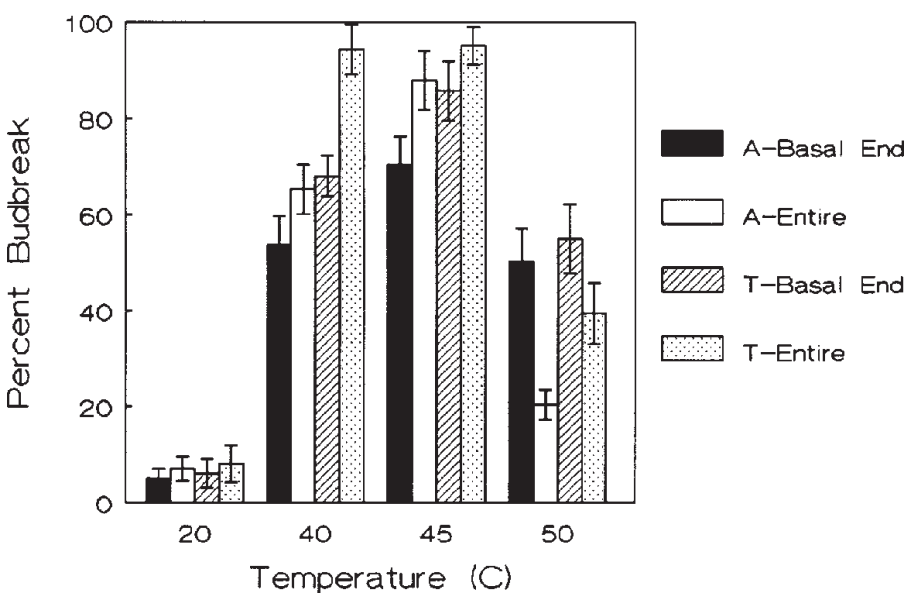

Fig. 2. Effect of heat (hot water) on budbreak of defoliated paradormant cuttings of 'Anna' apple axillary (A) and terminal (T) buds (after 21 days). Basal end: only the basal parts of shoots, $\approx 2.5 \mathrm{~cm}$ long, were immersed in hot water. Entire: entire shoots were immersed in hot water. The duration of each hot water treatment was $1 \mathrm{~h}$. Phytotoxicity occurred at 50C. Vertical bars represent mean of three replications \pm SE.

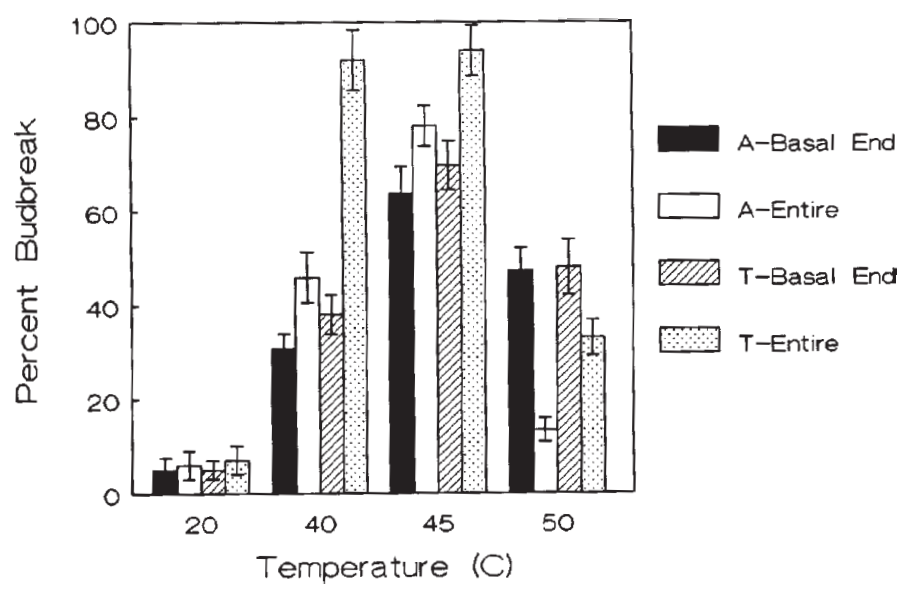

Fig. 3. Effect of heat (hot water on budbreak of defoliated endodormant cuttings of 'Anna' apple axillary (A) and terminal (T) buds (after 21 days). Basal end: only the basal parts of shoots, $\approx 2.5 \mathrm{~cm}$ long, were immersed in hot water. Entire: entire shoots were immersed in hot water. The duration of each hot water treatment was $1 \mathrm{~h}$. Phytotoxicity occurred at $50 \mathrm{C}$. Vertical bars represent mean of three replications $\pm \mathrm{SE}$. 


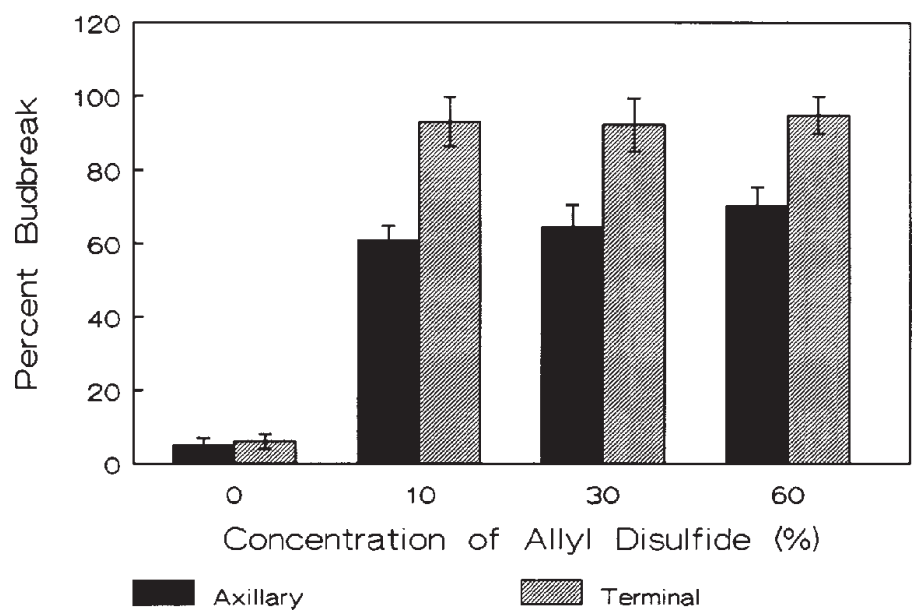

Fig. 4. Effect of volatiles from various concentrations of allyl disulfide on budbreak of defoliated paradormant cuttings of 'Anna' apple (after 21 days). Vertical bars represent mean of three replications \pm sE.

and a decrease in dehydroascorbic acid content in the buds (Tables 1 and 2). Our previous findings from electron spin resonance signals indicated that free radicals are formed in dormant buds (Wang and Faust, 1988) and thidiazuron activates a peroxidescavenging system, which eliminates free radicals as budbreak occurs. Presumably, the removal of free radicals promotes budbreak (Wang and Faust, 1988, 1992; Wang et al., 1991a, 1991b, 1991d). Free radical removal usually occurs through a series of oxidation-reduction reactions involving the removal of $\mathrm{H}_{2} \mathrm{O}_{2}$ and the use of ascorbate and glutathione as antioxidants (Dalton et al.,

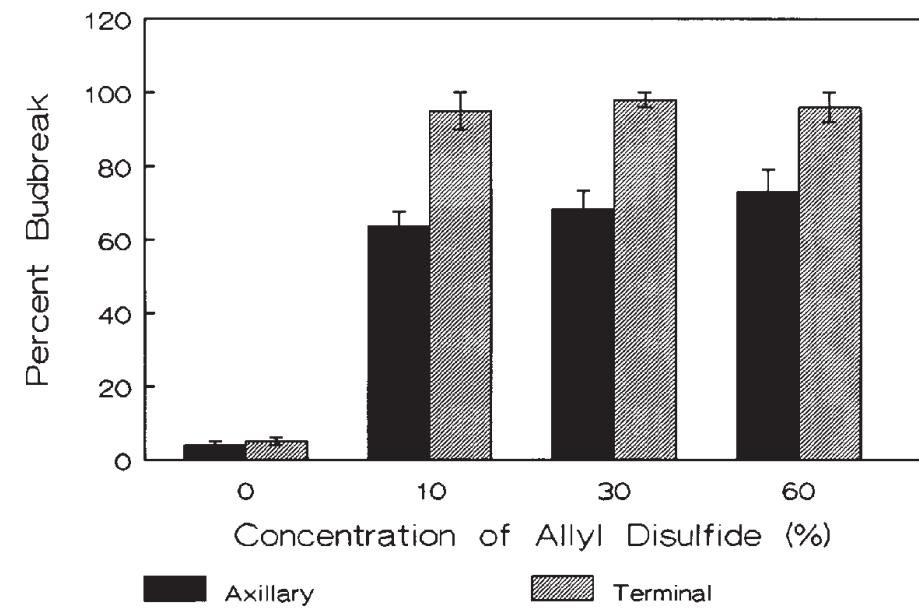

Fig. 5. Effect of volatiles from various concentrations of allyl disulfide on budbreak of endodormant cuttings of 'Anna' apple (after 21 days). Vertical bars represent mean of three replications \pm SE.

1987). Increased ascorbic acid, decreased dehydroascorbic acid, and the increase in the ratio of ascorbic acid to dehydroascorbic acid in apple buds after cold storage, hot water, and allyl disulfide treatments may allow for the removal of free radicals, which are all associated with budbreak.

The enzymes associated with peroxidase scavenging systems are AFR, ascorbate peroxidase, DHAR, and ascorbate oxidase. The activities of these enzymes increased when budbreak was induced by hot water, cold temperature, allyl disulfide (Tables 1 and 2), or thidiazuron (Wang and Faust, 1992; Wang et al., 1991a).

Table 1. Effect of heat (45C, $1 \mathrm{~h}$ ), cold [400 chilling units (CUs)], and allyl disulfide (30\%) on ascorbate and related enzyme activities in paradormant 'Anna' apple buds. Buds were collected and assayed 2 days after treatments.

\begin{tabular}{|c|c|c|c|c|}
\hline \multirow[b]{2}{*}{ Enzyme $^{y}$} & \multicolumn{4}{|c|}{ Treatment $^{\mathrm{Z}}$} \\
\hline & Control & $\begin{array}{l}\text { Heat } \\
(45 C)\end{array}$ & $\begin{array}{c}\text { Cold } \\
\text { (400 CUs) }\end{array}$ & $\begin{array}{c}\text { Allyl } \\
\text { disulfide } \\
(30 \%)\end{array}$ \\
\hline 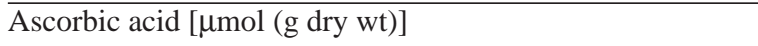 & $1.9 \pm 0.5$ & $6.9 \pm 1.1$ & $5.1 \pm 0.9$ & $5.3 \pm 0.9$ \\
\hline Dehydroascorbate $[\mu \mathrm{mol}$ (g dry wt)] & $0.9 \pm 0.1$ & $0.5 \pm 0.1$ & $0.5 \pm 0.1$ & $0.6 \pm 0.1$ \\
\hline AFR (nmol NADH/mg protein per min) & $52.3 \pm 2.6$ & $80.5 \pm 3.6$ & $70.4 \pm 2.0$ & $68.2 \pm 4.7$ \\
\hline DHAR (nmol NADPH/mg protein per min) & $58.2 \pm 6.5$ & $102.8 \pm 12.8$ & $112.7 \pm 10.4$ & $92.6 \pm 7.4$ \\
\hline Ascorbate peroxidase (nmol ascorbate/mg protein per min) & $98.2 \pm 9.7$ & $130.8 \pm 11.6$ & $125.4 \pm 10.3$ & $119.5 \pm 14.2$ \\
\hline Ascorbate oxidase $\left(\mathrm{nmol} \mathrm{O}_{2} / \mathrm{g}\right.$ protein per min) & $1.4 \pm 0.1$ & $3.4 \pm 0.3$ & $3.0 \pm 0.2$ & $3.1 \pm 0.3$ \\
\hline
\end{tabular}

${ }^{\mathrm{z}}$ Means of three replications $\pm \mathrm{SE}$

${ }^{\mathrm{y}} \mathrm{AFR}=$ ascorbate free radical reductase; DHAR = dehydroascorbate reductase

Table 2. Effect of heat (45C, $1 \mathrm{~h}$ ), cold [400 chilling units (CUs)], and allyl disulfide (30\%) on ascorbate and related enzyme activities in endodormant 'Anna' apple buds. Buds were collected and assayed 2 days after treatments.

\begin{tabular}{|c|c|c|c|c|}
\hline \multirow[b]{2}{*}{ Enzyme $^{\mathrm{y}}$} & \multicolumn{4}{|c|}{ Treatment $^{2}$} \\
\hline & Control & $\begin{array}{l}\text { Heat } \\
(45 C)\end{array}$ & $\begin{array}{c}\text { Cold } \\
\text { (400 CUs) }\end{array}$ & $\begin{array}{c}\text { Allyl } \\
\text { disulfide } \\
(30 \%)\end{array}$ \\
\hline Ascorbic acid $[\mu \mathrm{mol}(\mathrm{g}$ dry $\mathrm{wt})]$ & $2.4 \pm 0.5$ & $6.5 \pm 1.8$ & $6.2 \pm 1.1$ & $7.0 \pm 1.2$ \\
\hline Dehydroascorbate [mmol (g dry wt)] & $1.2 \pm 0.3$ & $0.7 \pm 0.2$ & $0.6 \pm 0.2$ & $0.7 \pm 0.3$ \\
\hline AFR (nmol NADH/mg protein per min) & $56.2 \pm 2.8$ & $75.4 \pm 3.3$ & $71.3 \pm 2.4$ & $73.8 \pm 4.1$ \\
\hline DHAR (nmol NADPH/mg protein per min) & $60.3 \pm 6.7$ & $98.7 \pm 11.5$ & $105.3 \pm 9.7$ & $100.2 \pm 8.9$ \\
\hline Ascorbate peroxidase (nmol ascorbate/mg protein per min) & $95.4 \pm 10.1$ & $135.7 \pm 12.4$ & $130.6 \pm 11.5$ & $129.0 \pm 11.7$ \\
\hline Ascorbate oxidase $\left(\mathrm{nmol} \mathrm{O}_{2} / \mathrm{g}\right.$ protein per min) & $1.8 \pm 0.3$ & $5.7 \pm 0.4$ & $5.1 \pm 0.2$ & $4.9 \pm 0.3$ \\
\hline
\end{tabular}

${ }^{\mathrm{z}}$ Means of three replications \pm SE.

${ }^{\mathrm{y}} \mathrm{AFR}=$ ascorbate free radical reductase DHAR $=$ dehydroascorbate reductase. 
Ascorbate free radicals are generated in biological systems by the reaction of ascorbate with superoxide anions, peroxides, or ascorbate oxidase (Arrigoni et al., 1981). AFR catalyzes the regeneration of ascorbate from ascorbate free radicals that were produced by ascorbate peroxidase or by nonenzymatic reactions (Arrigoni et al., 1981). DHAR plays a minor role in maintaining the ascorbic acid system in the reduced state (Borraccino et al., 1989; Hossain et al., 1984). AAO catalyzes the oxidation of ascorbate to 2-dehydroascorbate with the concomitant reduction of molecular oxygen to water (Ohkawa et al., 1989). The concurrent increase in the concentration of ascorbate and the activities of AFR, DHAR, ascorbate peroxidase, and ascorbate oxidase during the induction of budbreak in paradormant or endodormant buds by treatment with high or low temperatures or by allyl disulfide indicates that an increased capacity for free-radical scavenging is associated with budbreak. AAO is largely localized in the cell walls of apple buds (Wang and Faust, 1992). High AAO activity is characteristic of diverse, actively growing tissue (Newcomb, 1951). The increase in AAO activity does not necessarily mean that ascorbate is converted into dehydroascorbate and it might also be involved the reorganization of cell walls in apple buds to allow for the bud's growth, as in several other higher plants (Lin and Varner, 1991).

Changes of NPSH, RSH, total glutathione, and GR in apple buds treated with cold temperature, hot water, and allyl disulfide. GSH represented the largest fraction of NPSH, comprising $>70 \%$ of the total nonprotein sulfhydryl compounds in apple buds (Tables 3 and 4).
Increases in total glutathione, GSH, and other nonprotein thiols (NPSH, RSH) were associated with budbreak of endo- and paradormant buds treated with cold, hot water, and allyl disulfide (Tables 3 and 4). Wang et al. (1991a) found an increase in glutathione content during thidiazuron-induced budbreak of apple. Siller-Cepeda et al. (1992) reported a high GSH content in peach buds that was triggered by cyanamide treatment. Nieto-Sotelo et al. (1986) also described that heat stress increases total glutathione concentration in maize roots.

The role of RSH in apple buds relative to budbreak is unclear. It is possible that RSH may be a precursor or breakdown product of GSH. The major portion of glutathione in the cell is maintained in the reduced state by GR. GSH is an effective detoxifying agent and plays a general role as an oxidant scavenger (Kosower and Kosower, 1978). It serves as a substrate for DHAR and is also able to react directly with free radicals, including the hydroxy radical, which prevents the activation of enzymes by oxidizing essential thiol groups (Kosower and Kosower, 1978).

High concentrations of GSSG inhibit the initiation of protein synthesis and lead to the conversion of polysomes to monosomes (Kosower et al., 1972). In 'Anna' buds exposed to cold temperature, heat, and allyl disulfide, GSSG was depleted and GSH increased, thus increasing the GSH : GSSG ratio. (Tables 3 and 4). A high GSH : GSSG ratio could promote protein synthesis by controlling monosome formation (Fahey et al., 1975), activating and deactivating redox-dependent enzyme systems (Ziegler, 1985),

Table 3. Effect of heat (45C, $1 \mathrm{~h}$ ), cold [400 chilling units (CUs)], and allyl disulfide (30\%) on glutathione and glutathione reductase activity in paradormant 'Anna' apple buds. Buds were collected and assayed 2 days after treatments.

\begin{tabular}{|c|c|c|c|c|}
\hline \multirow[b]{2}{*}{ Enzyme $^{y}$} & \multicolumn{4}{|c|}{ Treatment $^{2}$} \\
\hline & Control & $\begin{array}{l}\text { Heat } \\
(45 C)\end{array}$ & $\begin{array}{c}\text { Cold } \\
\text { (400 CUs) }\end{array}$ & $\begin{array}{c}\text { Allyl } \\
\text { disulfide } \\
(30 \%)\end{array}$ \\
\hline$\overline{\mathrm{NPSH}}[\mu \mathrm{mol}(\mathrm{g}$ dry $\mathrm{wt})]$ & $65.2 \pm 4.5$ & $88.7 \pm 5.9$ & $84.7 \pm 4.7$ & $92.2 \pm 5.8$ \\
\hline $\mathrm{RSH}[\mu \mathrm{mol}(\mathrm{g}$ dry $\mathrm{wt})]$ & $19.0 \pm 1.1$ & $23.2 \pm 2.3$ & $23.8 \pm 2.1$ & $22.3 \pm 1.9$ \\
\hline Total glutathione $[\mu \mathrm{mol}(\mathrm{g}$ dry $\mathrm{wt})]$ & $60.4 \pm 3.1$ & $76.2 \pm 5.4$ & $73.4 \pm 6.2$ & $79.2 \pm 5.7$ \\
\hline GSH $[\mu \mathrm{mol}(\mathrm{g}$ dry wt) $]$ & $46.2 \pm 2.8$ & $65.5 \pm 4.3$ & $60.9 \pm 3.4$ & $69.9 \pm 7.2$ \\
\hline GSSG $[\mu \mathrm{mol}(\mathrm{g}$ dry $\mathrm{wt})]$ & $18.2 \pm 1.6$ & $10.7 \pm 0.9$ & $12.5 \pm 1.0$ & $9.3 \pm 0.7$ \\
\hline GSH : GSSG & $2.5 \pm 0.4$ & $6.1 \pm 0.7$ & $4.9 \pm 0.5$ & $7.5 \pm 0.8$ \\
\hline GR (nmol NADPH/mg protein per min) & $2.9 \pm 0.7$ & $20.2 \pm 1.5$ & $14.8+1.3$ & $24.6 \pm 2.1$ \\
\hline
\end{tabular}

${ }^{\mathrm{z}}$ Means of three replications \pm SE.

y NPSH = total nonprotein thiol; RSH nonglutathione thiol; GSH = reduced form of glutathione; GSSG = oxidized form of glutathione; $\mathrm{GR}=$ glutathione reductase.

Table 4. Effect of heat (45C, 1 h), cold [400 chilling units (CUs)], and allyl disulfide (30\%) on glutathione and glutathione reductase activity in endodormant 'Anna' apple buds. Buds were collected and assayed 2 days after treatments.

\begin{tabular}{|c|c|c|c|c|}
\hline \multirow[b]{2}{*}{ Enzyme $^{y}$} & \multicolumn{4}{|c|}{ Treatment $^{2}$} \\
\hline & Control & $\begin{array}{l}\text { Heat } \\
(45 C)\end{array}$ & $\begin{array}{c}\text { Cold } \\
\text { (400 CUs) }\end{array}$ & $\begin{array}{c}\text { Allyl } \\
\text { disulfide } \\
(30 \%)\end{array}$ \\
\hline NPSH $[\mu \mathrm{mol}(\mathrm{g}$ dry $\mathrm{wt})]$ & $70.2 \pm 5.4$ & $90.1 \pm 6.2$ & $85.2 \pm 7.0$ & $95.1 \pm 7.0$ \\
\hline $\mathrm{RSH}[\mu \mathrm{mol}(\mathrm{g}$ dry $\mathrm{wt})]$ & $19.5 \pm 2.3$ & $22.7 \pm 3.0$ & $22.8 \pm 2.9$ & $24.9 \pm 3.1$ \\
\hline Total glutathione [ $\mu \mathrm{mol}(\mathrm{g}$ dry $\mathrm{wt})]$ & $66.8 \pm 4.5$ & $79.9+5.4$ & $75.4 \pm 6.3$ & $81.1 \pm 6.7$ \\
\hline GSH $[\mu \mathrm{mol}(\mathrm{g}$ dry wt) $]$ & $50.7 \pm 2.8$ & $67.4 \pm 4.8$ & $62.4 \pm 3.9$ & $70.2 \pm 6.4$ \\
\hline GSSG $[\mu \mathrm{mol}(\mathrm{g}$ dry wt)] & $16.1 \pm 1.8$ & $12.5 \pm 1.1$ & $13.0 \pm 1.5$ & $10.9 \pm 1.0$ \\
\hline GSH : GSSG & $3.1 \pm 0.4$ & $5.4 \pm 0.6$ & $4.8 \pm 0.5$ & $6.4 \pm 0.7$ \\
\hline GR (nmol NADPH/mg protein per min & $3.5 \pm 1.0$ & $15.4 \pm 1.8$ & $14.2 \pm 1.8$ & $18.4 \pm 2.1$ \\
\hline
\end{tabular}

${ }^{\mathrm{z}}$ Means of three replications \pm SE.

${ }^{\mathrm{y}} \mathrm{NPSH}=$ total nonprotein thiol; $\mathrm{RSH}=$ nonglutathione thiol; $\mathrm{GSH}=$ reduced form of glutathione; GSSG = oxidized form of glutathione; GR = glutathione reductase. 
and regenerating the cellular antioxidant ascorbic acid under oxidative conditions (Foyer and Halliwell, 1976). Increased GSH and ascorbic acid content in apple buds may allow for the removal of free radicals that are associated with budbreak (Wang et al., 1991a).

GR catalyzes the NADPH-dependent reduction of GSSG to GSH (Jocelyn, 1972). Increased GR specific activity was associated with budbreak induced by cold temperature, heat, and allyl disulfide (Tables 3 and 4). High GR activity and a high level of GSH may serve as protective devices in maintaining a high-SH content in the buds to induce budbreak.

In this study, we found that cold, heat, and allyl disulfide overcame paradormancy and endodormancy in apple buds. These treatments increased ascorbic acid, total glutathione, GSH, NPSH, and RSH; dehydroascorbic acid and GSSG decreased. These treatments also increased the ratios of ascorbate: dehydroascorbate and GSH : GSSG and activities of AFR, ascorbate peroxidase, DHAR, ascorbate oxidase, and GR. Based on recent studies (Wang and Faust, 1992; Wang et al., 1991a-d) and the results presented here, a proposed scheme of ascorbate-glutathione cycle associated with budbreak for removing free radicals in apple buds is summarized in Fig. 6. This scheme suggests that budbreak induced by dormancy-breaking treatments might involve the removal of free radicals through a system using ascorbate as an antioxidant and producing dehydroascorbate by ascorbate peroxidase. Ascorbate may be regenerated in a GSH-dependent reaction catalyzed by AFR and DHAR. The GSSG is then reduced back to GSH in a reaction involving GR and NADPH. High ascorbic acid content and high activities of AFR, DHAR, and ascorbate peroxidase could increase the capacity for free-radical scavenging. The high activity of GR and a high level of GSH may play an important role as antioxidants and could prevent the formation of $\mathrm{S}-\mathrm{S}$ bonds, thereby inducing budbreak for resumption of growth in apple.

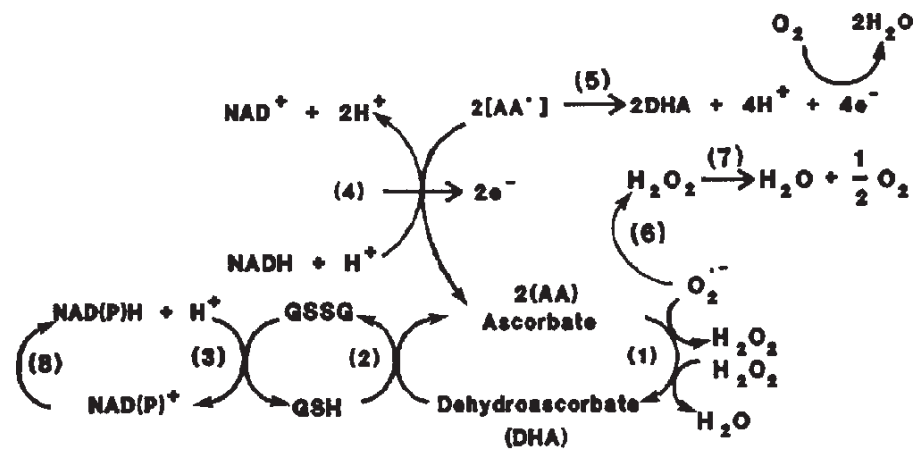

1. Ascorbate peroxidase

2. Dehydroascorbate reductase

3. Glutathione reductase

4. Ascorbate free radical reductase

5. Ascorbate oxidase

6. Superoxide dismutase

7. Catalase or ascorbate peroxidase

8. Pentose phosphate pathway

Fig. 6. A proposed scheme of the ascorbate-glutathione cycle associated with budbreak for removing free radicals in apple buds.

\section{Literature Cited}

Arakawa, N., K. Tsutsumi, N.G. Sanceda, T. Kurata, and C. Inagaki. 1981. A rapid and sensitive method for the determination of ascorbic acid using 4,7-diphenyl-1,10-phenanthroline. Agr. Biol. Chem. 45:1289-1290.

Arrigoni, O., S. Dipierro, and G. Borraccino. 1981. Ascorbate free radical reductase, a key enzyme of the ascorbic acid system. FEBS Lett. 125:242-245.

Boresch, K. 1924-28. Zur Analyse der fruhtreibenden Wirkung des Warmades. Biochem. Zeitschr. 153:313-343; 170:466-496; 202:180 201.

Borraccino, G., S. Dipierro, and O. Arrigoni. 1989. Interaction of ascorbate free radical reductase with sulfhydryl reagents. Phytochemistry 28:715-717.

Bradford, M.M. 1976. A rapid and sensitive method for the quantitation of microgram quantities of protein utilizing the principle of protein-dye binding. Anal. Biochem. 72:248-254.

Dalton, D.A., F.J.Hanus, S.A. Russell, and H.J.Evans. 1987. Purification, properties, and distribution of ascorbate peroxidase in legume root nodules. Plant Physiol. 83:789-794.

Ellman, G.L. 1959. Tissue sulfhydryl groups. Arch. Biochem. Biophys. 82:70-77.

Erez, A. and S. Lavee. 1971. The effect of climatic conditions on dormancy development of peach buds: I. Temperature. J. Amer. Soc. Hort. Sci. 96:711-714.

Fahey, R.C., S. Brody, and S.D. Mikolajczyk. 1975. Changes in the glutathione thio-disulfide status of Neurospora crassa conidia during germination and aging. J. Bacteriol. 121:144-151.

Foyer, C.H. and B. Halliwell. 1976. The presence of glutathione and glutathione reductase in chloroplasts: A proposed role in ascorbic acid metabolism. Planta 133:21-25.

Fuchigami, L.H. and C.C. Nee. 1987. Degree growth stage model and rest-breaking mechanisms in temperate woody perennials. HortScience 22:836-845

Guy, C.L. and J.V.Carter. 1982. Effect of low temperature on the glutathione status of plant cells, p. 169-179. In: P.H. Li and A. Sakai (eds.). Plant cold hardiness and freezing stress. vol. 2. Academic, New York.

Hosoki, T. and T. Kubara. 1989. Breaking corn dormancy and accelerated flowering of gladiolus with methyl disulfide. HortScience 24:968-971.

Hosoki, T., Y. Sakai, M. Hamada, and K. Taketani. 1986. Breaking bud dormancy in corns and trees with sulfide compounds in garlic and horseradish. HortScience 21:114-116.

Hossain, M.A., Y. Nakono, and K. Asada. 1984. Monodehydroascorbate reductase in spinach chloroplasts and its participation in regeneration of ascorbate for scavenging hydrogen peroxide. Plant Cell Physiol. 25:385395.

Jocelyn, P.C. 1972. Biochemistry of the SH group. Academic Press, New York.

Kosower, N.S. and E.M. Kosower. 1978. The glutathione status of cells. Intl. Rev. Cytol. 54:109-160.

Kosower, N.S., G.A. Vanderhoff, and E.M. Kosower. 1972. Glutathione. VIII. The effects of glutathione disulfide on initiation of protein synthesis. Biochim. Biophys. Acta 772:623-637.

Kubota, N. and K. Kawazu. 1992. Active substances in Chinese chive and rakkyo plants for breaking bud dormancy in grapevines. HortScience 27:689. (Abstr.)

Kubota, N. and M. Miyamuki. 1992. Breaking bud dormancy in grapevines with garlic paste. J. Amer. Soc. Hort. Sci. 117:898-902.

Lin, L.S. and J.E. Varner. 1991. Expression of ascorbic acid oxidase in zucchini squash (Cucurbita pepo L.). Plant Physiol. 96:159-165.

Molisch, H. 1908-09. Uber ein einfaches Verfahren, Pfanzen zu treien (Warmbadmethode). K. Akad. der Wiss. Wien, Math.-Nat. Kl. Sitzber. Abt. I. 117:87-117; 118:637-692.

Nakagawara, S. and S. Sagisak. 1984. Increase in enzyme activities related to ascorbate metabolism during cold acclimation of poplar twigs. Plant Cell Physiol. 25:899-906. 
Newcomb, E.H. 1951. Effect of auxin on ascorbic oxidase activity in tobacco pith cells. Proc. Soc. Expt. Biol. Medical 76:504-509.

Nieto-Sotelo, J. and T.-H.D. Ho. 1986. Regulation of the synthesis of heat-shock protein 58 by glutathione and cysteine in maizeroots during heat stress. Plant Physiol. 80(4):110. (Abstr.)

Ohkawa, J., N. Okada, A. Shinmyo, and M. Takano. 1989. Primary structure of cucumber (Cucumis sativus) ascorbate oxidase deduced from cDNA sequence: Homology with blue copper proteins and tissue specific expression. Proc. Natl. Acad. Sci. USA 86:1239-1243.

Orffer, C.J. and P.G. Goussard. 1980. Effect of hot water treatments on bud burst and rooting of grapevine cuttings. Vitis 19:1-3.

Paiva, E. and H.A. Robitaille. 1978. Breaking bud rest on detached apple shoots: Effects of wounding and ethylene. J. Amer. Soc Hort. Sci. 103:101-104.

Saure, M.C. 1985. Dormancy release in deciduous fruit trees. Hort. Rev. 7:239-300

Shigeoka, S., Y. Nakano, and S. Kitaoka. 1980. Metabolism of hydrogen peroxide in Euglena gracilis z by L-ascorbic acid peroxidase. Biochem. J. 186:377-380.

Shirazi, A.M. and L.H. Fuchigami. 1992. Near-lethal stress effects on endo-dormancy, cold acclimation, and recovery of Red-Osier dogwood plants. HortScience. 27:685. (Abstr.)

Siller-Cepeda, J.H., L.H. Fuchigami, and T.H.H. Chen. 1992. Glutathione content in peach buds in relation to development and release of rest. Plant Cell Physiol. 33:867-872.

Steffens, G.L. and G.W. Stutte. 1989. Thidiazuron substitution for chilling requirement in three apple cultivars. J. Plant Growth Regulat. 8:301-308.
Wang, S.Y. and M. Faust. 1988. Metabolic activities during dormancy and blooming of deciduous fruit trees. Israel J. Bot. 37:227-243.

Wang, S.Y. and M. Faust. 1992. Ascorbic acid oxidase activity in apple buds: Relation to thidiazuron-induced lateral budbreak. HortScience 27:1102-1105.

Wang, S.Y., and H.J. Jiao, and M. Faust. 1991a. Changes in ascorbate, glutathione, and related enzyme activities during thidiazuron-induced bud break of apple. Physiol. Plant. 82:231-236.

Wang, S.Y., H.J. Jiao, and M. Faust. 1991b. Changes in the activities of catalase, peroxidase, and polyphenol oxidase in apple buds during bud break induced by thidiazuron. J. Plant Growth Regulat. 10:33-39.

Wang, S.Y., H.J. Jiao, and M. Faust. 1991c. Changes in metabolic enzyme activities during thidiazuron-induced lateral budbreak of apple. HortScience 26:171-173.

Wang, S.Y., H.J. Jiao, and M. Faust. 1991d. Changes in superoxide dismutase activity during thidiazuron-induced budbreak of apple. HortScience 26:1202-1204.

Wang, S.Y., G.L. Steffens, and M. Faust. 1986. Breaking bud dormancy in apple with a plant bioregulator, thidiazuron. Phytochemistry 25:311-317.

Young, E. 1992. Timing of high temperature influences chilling negation in dormant apple trees. J. Amer. Soc. Hort. Sci. 117:271-272.

Ziegler, D.M. 1985. Role of reversible oxidation-reduction of enzyme thiols-disulfides in metabolic regulation. Annu. Rev. Biochem. 54:305329.

Zimmerman, R.H., M. Lieberman, and O.C. Broome. 1977. Inhibitory effect of a rhizobitoxine analog on bud growth after release from dormancy. Plant Physiol. 59:158-160. 